\title{
Children as Tortfeasors Under Italian LaW
}

\author{
Giovanni Comandé and Luca Nocco
}

\section{Short Introduction}

As a preliminary remark, we need to mention that the rules of tort law apply equally to both adults and children. ${ }^{1}$ Indeed, children can be liable under the general rules of tort law provided by artt. 2043 et seq. of the Italian civil code (Codice civile, c.c. ${ }^{2}$ ), since no minimum age has been fixed by the legislature as a condition for liability. However, courts have progressively adapted these rules to the peculiarities of torts involving children, in cases where they are either victims or tortfeasors.

Italian tort law provides that in order to be held liable, one must be "capable of understanding or intending at the time he committed the act causing injury". 3 This general rule of liability provided by art. 2046 c.c., ${ }^{4}$ requires the capacity to act reasonably and has been interpreted in the sense that a person should be

1 We will assume hereinafter that the word "children" are minors of 18 years old. See Law No. 39 of 8 March 1975. For a general introduction to minors under Italian law see F. Giardina, La condizione giuridica del minore (1984) and F. Giardina, voce Minore (Diritto civile) in: Enc. Giur. Treccani, XX (1990). A critical approach to current Italian law, too sharply distinguishing between minors and full age individuals is, among others, in E. Calò, Appunti sulla capacità d'agire dei minori, [1997] Diritto della famiglia e delle persone (Dir. fam. pers.), 1604 et seq. The interplay between minors and tort law is in S. Patti, Famiglia e responsabilità civile (1984), passim; F.D. Busnelli, Nuove frontiere della responsabilità civile, [1976] Jus, 64; M. Mantovani, Responsabilità dei genitori, dei tutori, dei precettori e dei maestri d'arte in: La responsabilità civile, II, 1 (1987); A. Scarpa, Il diritto ad essere minore, [1976] Archivio civile (Arch. civ.), 665 et seq.; R. Scionti, Sulla responsabilità dei genitori ex art. 2048 c.c., [1978] Dir. fam. pers., 1014; B. Pagliara, L'obbligazione dei genitori al risarcimento del danno per i danni cagionati dai figli minori, [1979] Diritto e pratica nell'assicurazione (Dir. prat. ass.), 30. See also P. Stanzione, Diritti esistenziali della persona, tutela delle minorità e Drittwirkung nell'esperienza europea, [2002] Europa e diritto privato (Eur. dir. priv.), 41 et seq.; and E. Quadri, L'interesse del minore nel sistema della legge civile, [1999] Famiglia e diritto (Fam. dir.), 80 for an analysis of the interplay between fundamental rights and legal rules applicable to children.

2 Enacted in 1942. Translations of c.c. articles are from M. Beltramo/G.E. Longo/J.H. Merryman (eds.), The Italian civil code and ancillary legislation (1969).

3 Art. 2046 c.c., the "capacità d'intendere o di volere al momento della commissione del fatto".

4 Art. 2046 c.c.: "A person who was incapable of understanding or intending at the time he committed the act causing injury is not liable for its consequences, unless the state of incapacity was caused by his own fault. Those who are not able to act reasonably are considered incapable." 
able to understand the implications of his/her action (or omission) and capable of self-determination.

3 While the civil code of 1865 provided for liability of parents, guardians and teachers in one article (art. 1153), in the civil code of 1942 there are several provisions dealing with parental or guardian's liability (mainly artt. $2047^{5}$ and $2048^{6}$ c.c.), which render de facto children's liability subsidiary to that of their father, mother, guardians, teachers and masters of apprentices (hereinafter "parents, etc."). To summarise, it could be said that the only consequence of minority in tort law is "to trigger a peculiar damages compensation system that involves the family".

4 It is important to stress from the outset the distinction which is made between a child who is "incapable of understanding or intending at the time he committed the act causing injury", following the wording of art. 2046 c.c., from one who is capable. In the first case, the child will be liable in tort and their parents, etc., are jointly and severally liable along with the child. In the second case, the parents, etc., are solely liable. Besides, minors can only be held liable in equity if the civil action against the parents, guardians, etc. fails.

5 In order to hold these persons liable for an incapable person's act (minor or not), it is necessary that the act has all the characteristics of a tort, barring the mental element that would have otherwise established capacity. In other words, art. 2047 c.c. does not make any reference to a "tort" committed by the

5 Art. 2047 c.c.: "If an injury is caused by a person incapable of understanding or intending, compensation is due from those who were charged with the custody of such person, unless they prove that the act could not have been prevented. If the person injured is unable to secure compensation from the person charged with the custody of the person lacking capacity, the court, considering the financial conditions of the parties, can order the person who caused the injury to pay an equitable compensation."

6 Art. 2048 c.c. "The father and mother, or the guardian, are liable for the damage occasioned by an unlawful act of their minor emancipated children, or of persons subject to their guardianship (343 et seq., 414) who reside with them. The same provision applies to a parent by affiliation. Teachers and others who teach an art, trade, or profession are liable for the damage occasioned by the unlawful act of their pupils or apprentices while they are under their supervision. The persons mentioned in the preceding paragraphs are only relieved of liability if they prove that they were unable to prevent the act". See, among several cases: Tribunale di Milano (First Instance Court, Trib.), 18 December 2001, [2002] Giustizia civile (GC), 2365 establishing that in order to apply art. 2047 c.c., the liable person must know the incapacity of the one who committed the fact. Hence, when parents do not know their child's state of incapacity, art. 2048 c.c. applies. In this case, parents relieve themselves from liability by showing that they properly supervised the child and offered proper education according to what is required by art. 147 c.c.

${ }^{7}$ F. Giardina, voce Minore (supra fn. 1), 3. The role of financial guarantee assumed by liability of parents in case law is stressed by A. Pinori, Sulla responsabilità dei genitori per culpa in educando ed in vigilando, [1995] Giurisprudenza italiana (GI), I, 2, 558 and S. Patti, L'illecito del "quasi maggiorenne" e la responsabilità dei genitori: il recente indirizzo del Bundesgerichtshof, [1984] Rivista di diritto commerciale (Riv. dir. comm.), 32. L. Corsaro, Funzione e ragioni della responsailità del genitore per il fatto illecito del figlio minore, [1998] GI, IV, 228 emphasises that this role is part of the parents' duties with regard to one's own children's behaviours capable of affecting third parties. See also F.D. Busnelli, Capacità ed incapacità d'agire del minore, [1982] Dir. fam. pers., 54 et seq. 
incapable person. On the contrary, art. 2048 c.c. postulates the illicit act of a minor, capable of understanding or intending at the time he committed the act causing the injury, for which parents (or guardians) might also be held liable, for their failure to educate or supervise the child properly. ${ }^{8}$ In other words, both the minor and the parents, etc., must have committed a tort; regarding the latter, it consists in the violation of the duty to properly educate and raise the child ${ }^{9}$ arising from art. 147 c.c. ${ }^{10}$ In light of this provision, judges must therefore ascertain both the tort committed by the child and the absence of evidence exonerating parents (or guardians) from their presumed defect in control or education. ${ }^{11}$ Nevertheless, the elimination of "the strong paternalistic accretions of our case law"12 may appear in conflict with maintaining an anachronistic sanction against parents "liable" for not having properly educated their children. ${ }^{13}$

Finally, when it is not possible to obtain compensation from the person who is legally liable for children's acts or omissions, the child that is not capable at the time of the act causing the injury could be held liable in equity (art. 2047 c.c.).

\section{Liability of the Child}

\section{A. Liability for Wrongful Acts}

\section{Is there a fixed minimum age for children to be liable?}

As mentioned previously, there is no fixed minimum age for children to be liable in tort; ${ }^{14}$ the general rule of liability is linked to the notion of capacity. Accordingly, liability is attributed if the person (either adult or child) is able to

8 Minors and parents' etc. liability concur. See Corte di cassazione, sezioni civili (Italian Supreme Court, Cass.) 3 March 1995, No. 2463, [1995] GC, I, 2093, with comment of F. Casini; Cass. 13 September 1996, No. 8263, [1997] Studium Juris, 80.

9 Cass. 9 October 1997, No. 9815, [1998] Studium Juris, 426.

10 Art. 147: "Marriage imposes on both spouses the obligation to maintain, educate and instruct the children taking into account their ability, natural inclination and aspirations." See A. Germanò, Potestà dei genitori e diritti fondamentali dei minori, [1979] Dir. fam. pers., 1514 et seq.

11 Difficulties in the application of artt. 2047 and 2048 c.c. have led some scholars to wonder whether these rules are up-to-date. See P. Morozzo della Rocca, La responsabilità civile dei genitori, tutori, maestri in: P. Cendon (ed.), La responsabilità civile (1998), 39 and 44. Furthermore, see R. Pardolesi, Danni cagionati dai minori: pagano sempre i genitori?, [1997] Fam. dir., 225.

12 This way F. Giardina, I rapporti personali tra genitori e figli alla luce del nuovo diritto di famiglia, [1977] Rivista trimestrale di diritto e procedura civile (Riv. trim. dir. proc. Civ.), 1352 et seq.

13 Similar doubts are in V. Carbone, Non rispondono i genitori per gli incidenti causati dal minore in motorino, [2001] Danno e Responsabilità (DR), 501 et seq.; and in S. Patti (supra fn. 7), 29 et seq.; comparing with similar results the German and Italian law. See also, S. Patti, [1984] Riv. Dir. Comm., 30, fn. 7, where the author stresses that courts do not actually ask themselves in which way parents could have prevented several activities they do not even know their children are performing. More recently see R. Pardolesi (supra fn. 11), 225.

${ }^{14}$ It is necessary to mention art. 2 c.c., which sets the legal capacity to exercise rights at the majority age of 18 ("al compimento del diciottesimo anno"). 
understand the general implications of his/her actions or omissions. Please refer above under nos. 3-6.

8 In the civil code, the legislature has moved away from the solution reached in the criminal field. In fact, the criminal code of 1930 (Codice penale, c.p.) ${ }^{15}$ provides a general principle expressed in terms of "capacity to act reasonably"16 (art. 85 c.p.) which is completed by specific rules for minors which follow this general provision. ${ }^{17}$ According to those rules, minors up to 14 years of age can never be liable for the crimes they have committed. However, minors between 14 and 18 years of age can be held liable for a crime, if it is proved that they had the "capacità d'intendere e di volere". ${ }^{18}$ In any event, their sentence is reduced with respect to the usual rules applicable to adults with capacity.

9 Those special provisions of the criminal code are not applicable in civil actions, even by analogy. ${ }^{19}$ Nevertheless, very often judges do not even test whether a child between one to six years of age has capacity ("capacità di intendere o di volere"). ${ }^{20}$ They presume, owing to the very young age of the tortfeasor, an incapacity "in re ipsa".

10 Art. 2 of law no. 689 of 24 November 1981 excludes the liability of minors of eighteen with regard to administrative sanctions. On the contrary, the same law establishes the liability of their guardians, unless the guardian proves that the act could not have been prevented. Scholars ${ }^{21}$ have been very critical of this exemption from liability, because it does not take into account the actual freedom that minors enjoy today; freedom that should be linked to a corre-

15 Codice penale (Criminal Code, c.p.).

16 Art. 85 c.p.: "Nessuno può essere punito per un fatto preveduto dalla legge come reato, se, al momento in cui lo ha commesso, non era imputabile". (Translation of the author: "No one can be punished for a fact that is a crime if, at the time of it, it was not chargeable.").

17 Art. 97 c.p.: "Non è imputabile chi, nel momento in cui ha commesso il fatto, non aveva compiuto i quattordici anni" (Translation of the author: "A minor of 14 years is not chargeable."). Art. 98 c.p.: "È imputabile chi, nel momento in cui ha commesso il fatto, aveva compiuto i quattordici anni, ma non ancora i diciotto, se aveva capacità d'intendere e di volere; ma la pena è diminuita" (Translation of the author: "One who is 14 years old, but not yet 18 , is chargeable if, at the time of the commission of the act, s/he was capable of understanding or intending; but the penalty is reduced.").

18 A more extensive discussion on criteria to assess minors' intellectual maturity is in P.P. Martucci, Maturità psicofisica e imputabilità del minore, [2000] Fam. dir., 146 et seq.

19 Cass. 18 June 1953, no. 1812, [1953] Repertorio del Foro italiano (Foro it., Rep., voce Responsabilità civile), no. 94; Cass. 8 April 1965, no. 597, [1965] Foro it., Rep, voce Responsabilità civile, no. 153; Cass. 18 June 1975, no. 2425, [1975] Foro it., Rep., voce Responsabilità civile, no. 157; Corte di cassazione, sezioni unite (Italian Supreme Court, Cass., sez. un.), 6 December 1982, no. 6651, [1983] Il Foro italiano (Foro it.), I, 1630; Cass. 19 November 1990, no. 11163, [1990] Foro it., Rep., voce Responsabilità civile, no. 98.

${ }^{20}$ See Trib. Piacenza 4 March 1961, [1962] Archivio giuridico della circolazione (Arch giur. circ.), II, 290 and Corte di appello (Appeal Court, App.) Firenze 13 March 1964, [1964] Giurisprudenza toscana (Giur. tosc.), 598.

21 S. Verzaro, La prova liberatoria a carico dei genitori ex art. 2 1. 24 novembre 1981, no. 689, [1996] Responsabilità civile e previdenza (Resp. civ. prev.), 1159. 
sponding responsibility. Moreover, this exemption is in contrast with the corresponding provision of the criminal code, which penalises minors above fourteen years of age who are capable of understanding and intending. Furthermore, the courts' interpretation of art. 2048 c.c., especially strict against parents, ${ }^{22}$ creates compatibility problems between the provisions of art. 2 law $689 \backslash 1981$, on the one hand, and, on the other, both the general principle of personal responsibility and of necessary statutory intervention introduced by the same L. 689/81. ${ }^{23}$

\section{Is there a specific window within the life of a child during which the liability of the child depends on its capacity to act reasonably or any similar standard?}

As already mentioned, a specific distinction between the criminal and the civil code is that, while the first one typifies specific causes of non-liability ("non imputabilită"), ${ }^{24}$ the civil code leaves the issue of establishing liability in all cases to the discretion of the judges. They base their opinion upon the child's intellectual and physical faculties, incidental diseases, the way in which s/he behaved, his/her studies, education, and similar criteria. ${ }^{25}$ Therefore, to be held liable ${ }^{26}$ a child must be able to act reasonably; however, the specific "judicial presumption" of incapacity for children between the age of one to six years often applies (see above nos. 7 to 10).

Nevertheless, recent decisions of the Supreme Court of Cassazione have held that it is not enough for the judge to refer merely to age and to the fact causing injury in order to establish the minor's incapacity. The court should take into consideration the intellectual and physical capacity of children as well as their development, their character, their ability to perceive the illicit nature of their actions and their ability to make reasoned choices. The criteria for those evaluations are not fixed by law but should be established in light of common experience and scientific notions. ${ }^{27}$

${ }^{22}$ Please refer to nos. 42 et seq.

${ }^{23}$ See S. Verzaro (supra fn. 21), 1162.

${ }^{24}$ That is, the impossibility to be punished. Please refer to art. 88 et seq. c.p.

25 See Cass. 28 May 1975, no. 1642, [1975] Foro it., Rep., voce Responsabilità civile, no. 158159; Cass. 15 January 1980, no. 369, [1981] Il foro padano (Foro pad.), I, 329 and [1980] GI, I, 1, 1593; Cass. 30 January 1985, no. 565, [1985] Repertorio della Giurisprudenza italiana, voce Responsabilità civile (Giur. it., Rep., voce Responsabilità civile), no. 112; Cass. 26 June 2001, no. 8740, [2001] Foro it., I, 3098, with comment of F. di Ciommo and [2002] DR, 283, with comment of F. Agnino, Il fatto repentino ed improvviso esclude la responsabilità dei precettori.

${ }^{26}$ Cass. 4 April 1959, no. 1006, [1959] Foro it., I, 533, with comment of A. De Cupis.

${ }^{27}$ Cass. 26 June 2001, no. 8740, [2001] Foro it., I, 3098; Cass. 28 May 1975, no. 1642, [1975] Foro it., Rep., voce Responsabilità civile, no. 158-159. 
3. What is the exact significance of the term "capacity to act reasonably": Mere ability to realize the dangers of one's behaviour or as well the ability to adjust the behaviour according to this realization? Does the child have to realize the particular danger in the individual case (concrete danger), or is it sufficient that it understands that his action can in some way be dangerous (abstract danger)? Is the capacity to act reasonably measured by an objective standard referring to an ordinary child of the same age or is it determined by examining the capacity to act reasonably of the individual child?

13 Under Italian law, the expression "capacity to act reasonably" means to realise the dangers of one's own behaviour, as well as the ability to direct one's behaviour towards the achievement of one's purpose. In this sense, art. 2046 c.c. uses the term "intendere o volere" (understand or will), as opposed to "intendere e volere" (understand and will), while the lack of any of those requirements makes it impossible to hold a person liable. Most particularly, the expression "capacità d'intendere o di volere" is understood as being the ability of a person to understand the implications of his/her action or omission and, respectively, the aptitude to behave reasonably. ${ }^{28}$

14 Under Italian law, it is a highly controversial issue as to whether a child has to realise a particular danger in an individual case or if it is sufficient that $\mathrm{s} / \mathrm{he}$ understood the danger s/he creates by his/her own behaviour. Some scholars ${ }^{29}$ stress the necessity to ascertain whether the person was also actually able to understand the consequences of the action and/or the omission; according to them, a theoretical analysis is insufficient to trigger liability.

15 Besides, there are several contradicting opinions regarding the criteria to be used in determining whether a person behaves negligently. While some authors $^{30}$ believe it is necessary to establish negligence in the light of subjective standards, the majority conversely stress that negligence exists when a person behaves differently from a social or professional standard of conduct. ${ }^{31}$ This way, delictual capacity ("imputabilità"), as defined above, becomes a legal requirement for liability based on fault.

16 Note, however, that judges regularly presume incapacity of understanding or intending from the minority age and/or from the minor's education and upbringing. ${ }^{32}$

${ }^{28}$ See G. Marini, voce Imputabilità, in: Digesto delle discipline penalistiche (Digesto disc. pen.) (1992), VI, 253; A. Crespi, voce Imputabilità (diritto penale, dir. pen.), in: Enciclopedia del Diritto (Enc. dir.) (1970), XX, 772.

29 See E. Pellecchia, L'art. 2047 c.c. tra anacronismi e pericolose fughe in avanti: ovvero, quando l'infermo di mente, il sorvegliante e il danneggiato sono tutti vittime, [1994] Resp. civ. prev., 1074, for the specific case of a person with mental disorder (art. 2 c.c.), who is, like the child, "incapace d'agire".

${ }^{30}$ See, among several authors, C.M. Bianca, Diritto civile, V, La responsabilità (1994), 656.

31 See M. Comporti, Fatti illeciti: le responsabilità presunte. Artt. 2044-2048, in Comm. al Codice Civile Schlesinger-Busnelli (2002), 65 et seq.

32 Cass. 15 January 1980, no. 369, [1981] Foro pad., I, 329. Among criminal law experts please refer to A. DellaBella/G. Ripamonti, Minori e capacità di intendere e volere: una importante pronuncia del Tribunale di Milano, [2003] Cassazione penale (Cass. pen.), 1384 et seq. 
4. Is the appreciation of whether the child has a capacity to act reasonably in any way influenced by the fact of the child being covered by a (family) liability insurance policy? Is there such influence on the standard of care?

There is no evidence that appreciation of children's capacity to act reasonably is influenced either by parental liability or by the existence of a family liability insurance policy. Nevertheless, we assume that case law easily relies on the fact that parents are liable for their children acts, whether or not capable.

\section{What is the standard of care applicable to children?}

The standard of care applicable to children, as referred above, is not any different from the general one. If, when determining capacity ("capacità d'intendere o di volere" or "capacità naturale" - "natural capacity"), it seems that a child is able to understand the sense and the consequences of his/her conduct, s/he can be held liable. ${ }^{33}$

6. Are children held to a higher standard of care if they engage in "adult activities"?

It would appear that there is no difference as to the kind of activity the child engages in for determining the standard of care. However, different consequences may follow in different approaches to the legal requirements, as suggested by some scholars. Please refer to nos. 13 to 16 for more details.

\section{B. Liability in Equity}

7. May children be liable in equity if they have no capacity to act reasonably or if they act in accordance with the (lower) standard of care applicable to children but violate the general duty of care incumbent upon adults?

A child may be liable in equity if the victim cannot receive compensation from the person who is legally liable for the child's act causing damage. This principle is set out in art. 2047 c.c., second paragraph, which reduces greatly the immunity of children and individuals not able to act reasonably. Causes leading to an obligation to compensate damage sustained are: the absence of a person under a duty to supervise ${ }^{34}$ his/her insolvency; the proof that the person obliged to supervise the child could not avoid the damage.

In these cases, nevertheless, the tortfeasor cannot be compelled to pay the total amount of damages suffered by the victim. The child, for instance, will pay a fair indemnity ("equa indennità"), ${ }^{35}$ which is lower than the full loss. Accord-

${ }^{33}$ See Cass. 8 April 1965, no. 597, [1965] Foro it., Rep, voce Responsabilità civile, no. 153; Cass. 15 January 1980, no. 369, [1981] Foro pad., I, 329.

${ }^{34}$ Cass. 28 January 1953, no. 216, [1953] GI, 1953, I, 1, 496.

${ }^{35}$ This rule has been applied only a very few times. Among them: Cass. 28 January 1953, no. 216, [1953] GI, 1953, I, 1, 496 and App. Torino, 14 July 1956, [1956] GI, I, 2, 574. 
ing to some scholars ${ }^{36}$ though, this is a case in the civil code in which the judge has discretionary power to decide whether or not indemnity is due in its full amount.

22 It is controversial whether the award requires actual fault of the child ${ }^{37}$ or if it is rather a case of strict liability. ${ }^{38}$ Scholars almost unanimously hold that this is a rule based on equity; one author, however, argues that children's liability in equity can indeed be described as being a strict liability rule. ${ }^{39}$

23 In addition, one should remember that liability based on art. 2047 para. 2 c.c. is secondary. Thus, no one can be found liable under this provision if there is no principal debtor. ${ }^{40}$ Such would be the case if the supervisor were the injured person.

8. Is there a reduction clause as to the amount of damages owed by the child if it is not liable under the applicable standards and/or even if it is fully liable under the standard? What are the factors of equity? i) Intensity of violation of legal duty (negligence, gross negligence, intention); ii) Wealth of child and victim; iii) The fact of the child carrying liability insurance. If answered in the affirmative: Is there a difference between compulsory and optional liability insurance?; iv) The fact of the victim being insured against the loss by a private insurance company or the social security system.

24 If the child is liable in tort, there are no reduction clauses which differ from the regular ones (e.g. contributory negligence of the victim). However, in determining liability in equity under art. 2047 c.c., judges must take into account the economic conditions of the parties. ${ }^{41}$ This may lead de facto to a reduction in the amount of damages due (in equity) by a child.

${ }^{36}$ F.D. Busnelli/S. Patti (eds.), Danno e responsabilità civile (1997), 297, note 2, who stress the difference between this article of the civil code and art. 2045 c.c. ("Stato di necessità"), that obliges the judge to condemn the tortfeasor to pay the "indennità", and limits judicial powers only to determine the amount; art. 2045: "If a person who commits an act which causes injury was compelled by the necessity of saving himself or others from a present danger of serious personal injury, and the danger was neither voluntarily caused by him nor otherwise avoidable, the person injured is entitled to compensation in an amount equitably established by the court." See also S. Rodotà, Il problema della responsabilità civile (1967), 143.

37 C. Salvi, La responsabilità civile dell'infermo di mente in: P. Cendon (ed.), Un altro diritto per il malato di mente. Esperienze e soggetti della trasformazione (1988), 821.

${ }^{38}$ M. Comporti, Esposizione al pericolo e responsabilità civile (1965), 237 and M. Franzoni, Dei fatti illeciti, art. 2043-2059 in: F. Galgano (ed.), Commentario al codice civile Scialoja-Branca (1993), 342 et seq., who specifies that all the elements for establishing tort liability must be present, at least in abstracto.

39 M. Comporti, Fatti illeciti: le responsabilità presunte. artt. 2044-2048 in: Commentario Schlesinger-Busnelli (supra fn. 31), 342 et seq. and E. Bonvicni, La responsabilità civile per fatto altrui (1975), 635.

40 See Trib. Perugia 30 October 1995, [1996] Rassegna giuridica umbra, 89.

${ }^{41}$ See Trib. Macerata 20 May 1986, [1987] Resp. civ. prev., 107. 
According to one opinion, ${ }^{42}$ another basis for reduction concerns only the amount of non-pecuniary losses suffered by the victim of a child's tort. At first, judges affirmed that "danno non patrimoniale" - non-economic loss ought not to be compensated by reason of the effect of art. 2059 c.c. ${ }^{43}$ The underlying argument was to the effect that Italian law requires the commission of a crime in order to allow compensation for non-economic loss; such a rule was hardly compatible with the long established principle that only individuals over 14 of age can commit a crime. ${ }^{44}$ Another judicial trend, ${ }^{45}$ nowadays predominant, holds that in order for the victim to recover non-pecuniary damages, it is sufficient that the crime be ascertained in abstracto. Nonetheless, we were left with two contradictory decisions ${ }^{46}$ for which judges were obviously influenced by the dramatic factual context.

It must be added that, in May 2003, the Court of Cassazione changed its reading of all the liability rules whenever a presumption of liability applies, stating that non-patrimonial damages must be awarded also when liability is presumed and there is no positive evidence of negligence. ${ }^{47}$ The text of the decisions referred explicitly only to artt. 2050 to 2054 c.c.; however the reasoning behind them clearly applies to artt. 2047 and 2048 c.c. as well.

In summary, the recoverability of non-pecuniary losses when the tortfeasor is incapable of understanding or intending at the time of the commission of the

42 Cass. 4 April 1959, no. 1006, [1959] Foro it., I, 533; Cass. 29 October 1965, no. 2302, [1966] GI, I, 1, 1282; Cass. 26 July 1974, no. 2259, [1974] Foro it., Rep., voce Danni civili, no. 43; Trib. Venezia 14 July 1999, [2000] Foro pad., I, 428, with comment of G. Franceschini. See also G. Bonilini, Il danno non patrimoniale (1983), 515 and G. Visintini, Imputabilità e danno cagionato dall'incapace, [1986] Nuova giurisprudenza civile commentata (NGCC), II, 117.

43 See art. 2059: "Non-patrimonial damages shall be awarded in cases provided by law." See art. 185 c.p.: "Ogni reato obbliga alle restituzioni, a norma delle leggi civili. Ogni reato, che abbia cagionato un danno patrimoniale o non patrimoniale, obbliga al risarcimento il colpevole e le persone che, a norma delle leggi civili, debbono rispondere per il fatto di lui".

44 Please refer to the very recent decisions rendered by the Italian Supreme court and Constitutional court (Cass., 31 May 2003, no. 8827 and no. 8828, [2003] DR, 816 et seq., with comments of F.D. Busnelli, Chiaroscuri d'estate. La Corte di Cassazione e il danno alla persona; G. Ponzanelli, Ricomposizione dell'universo non patrimoniale: le scelte della Corte di Cassazione and A. Procida Mirabelli Di Lauro, L'art. 2059 c.c. va in paradiso and Corte Costituzionale 11 July 2003, no. 233, [2003] DR, 939 et seq. with comments of G. Ponzanelli, La corte costituzionale si allinea alla Corte di cassazione and A. Procida Mirabelli Di Lauro, Il sistema della responsabilità civile dopo la sentenza della Corte Costituzionale no. 233/03).

45 See Cass. 6 June 1977, no. 1623, [1977] Foro it., Rep., voce Danni civili, no. 28; Cass., sez. un., 6 December 1982, no. 6651, [1983] Foro it., I, 1630; Cass. 30 January 1985, no. 565, [1985] GI, voce Responsabilità civile, no. 112; Cass. 12 August 1995, no. 8845, [1995] Foro it., Rep., voce Danni civili, no. 156. See also V. Zeno Zencovich, Danni non patrimoniali e reato commesso dal non imputabile, [1983] Riv. dir. comm., II, 227; P. Ziviz, La tutela risarcitoria della persona (1999), 121; G.B. Petti, Il risarcimento del danno patrimoniale e non patrimoniale alla persona (1999), 123.

46 Trib. Trieste 23 November 1990, [1993] NGCC, 1993, I, 986 and Trib. Macerata 20 May 1986, [1987] Resp. civ. prev., 107.

47 Cass. 12 May 2003, no. 7281 and 7283, [2003] DR, 713 and Cass., 17 May 2003, no. 7282, [2003] Giustizia civile (Giust. civ.), I, 1480 et seq. 
act are particular cases in which the influence of equity upon compensation is obvious.

9. Is the liability in equity, if any, subsidiary to the liability of the legal guardian or has the latter liability priority?

28 The civil action for liability in equity provided for by art. 2047, para. 2 c.c. cannot succeed if the previous action against the father, mother, guardians, etc. who had custody of the incapable person (art. 2047, sec. 1, c.c.) has not come to an end. In other words, the judge can decide upon the action in equity against the tortfeasor without capacity only if the action against the guardians has failed. ${ }^{48}$

\section{Strict Liability}

10. Are children subject to regimes of strict liability like adults or are there special concepts to restrict their liability? In particular: May a child be a keeper of a dangerous thing, like a dog, a car or a plant?

29 Children are subject to strict liability under the same requirements as adults are. The scope of art. 2046 c.c. is debated under Italian law. Indeed, the possibility of declaring a minor liable in tort depends on liability capacity ("imputabilità") under negligence principles. Hence, when Italian law does not require negligence to be proved, art. 2046 c.c. is not applied. In other words, the general requirement of delictual capacity is not applied in cases in which a regime of strict liability is provided. Indeed, in those hypotheses, the law does not require negligence even for tortfeasors older than 18 years. ${ }^{49}$ This means that a child may actually be a keeper of a dog or a plant. ${ }^{50}$

\section{Insurance Matters}

11. a) Are children covered by family liability insurance policies? Do these policies cover the risk of liability only or is the liability cover part and parcel of a multi-risk insurance policy, e.g. part of a household contents or occupier's liability insurance?

30 It really depends on the insurance policy the family has taken out (if any). Usually, a family liability insurance policy covers all damage occurring in the private (i.e. non-professional) sphere of the family members. In any event, several clauses exclude damage caused intentionally from cover. Research

48 Trib. Orvieto 22 February 2001, [2001] Rass. giur. umbra, 38, with comment of G. Sangro.

49 M. Comporti (supra fn. 38); P. Trimarchi, Rischio e responsabilità oggettiva, (1961) 38; L. BigliazziGeri/U. Breccia/F.D. Busnelli/U. Natoli, Diritto civile 3 (1991), 696. Contra: C.M. Bianca (supra fn. 30), 656, note 5. For courts' decisions, see among several, Cass. 29 April 1993, no. 5024, [1994] Resp. civ. prev., 472.

${ }^{50}$ See V. Geri, La responsabilità civile da cose in custodia, animali, rovina di edificio (1973), 3 et seq. 
into the market has shown insurance policies exist against damage caused by any family members, unless caused while engaging in professional activities. Cover is also available for all personal injury and material damage involuntarily caused to third parties in relation to the property or rent of a building including that caused in the course of daily family life.

b) Whatever kind of insurance is available - are there efforts on the part of the insurance industry to risk-rate premiums, e.g. by making the level of premiums dependent on the number, sex, age and criminal history of the children in the particular family, by employing deductibles and/or bonus malus-systems or by reserving termination rights in case of repeated accidents?

To the best of our knowledge "bonus malus" clauses are mainly in the automobile liability insurance market. Their presence in other fields is rather minor.

12. a) How many per cent of families are covered by family liability insurance?

In Italy, family liability insurance is still not widely used. However, we were unable to find actual data on the issue. Nevertheless, the National Association of insurance confirmed that cover for family liability is offered in various forms (home insurance, multipurpose risk insurance, third-party liability). This makes monitoring it for percentages and prices very difficult. With regard to child-related tort liability, the named insurance policies cover the civil liability of the head of the family (or the person in charge of the child), along with their spouses and other relatives living with them. Accidents in the course of professional activities are excluded. These insurance policies cover all torts committed by the child, including those related to driving motor vehicles. $^{51}$

b) Does the liability insurance cover extend to intentional torts committed by the child?

As a general rule (art. 1900 c.c.), "the insurer is liable for the accident caused by intent or gross negligence of the individuals for whose action [or omission] the insured is liable". ${ }^{52}$ The underlying policy is to not frustrate the operation of the insurance in those cases where there is a presumption that the motive for taking out insurance was to provide cover for events for which the insured could be held liable. ${ }^{53}$ However, the contract may contain an exclusion clause

51 See Cass. 7 September 1977, no. 3907, [1979] GI, I, 1, 694.

52 G. Angeloni, voce Assicurazione della responsabilità civile, [1958] Enc. Dir., III, 557 et seq.; V. Salandra, Dell'assicurazione in: Commentario al codice civile Scialoja-Branca (1966), 333 and M. Rossetti, Commento sub art. 1917 c.c. in: A. La Torre (ed.), Le assicurazioni (2000), 243 et seq.

53 L. Farenga, Diritto delle assicurazioni private (2001), 99. See also D. de Strobel, L'assicurazione di responsabilità civile (3rd edn. 1992), 142 et seq. 
in favour of the insurer in the case of intent or gross negligence of those individuals for whom the insured is liable. ${ }^{54}$ There must be express written agreement to this clause, since it is proposed by the insurer, under art. 1341 c.c. ${ }^{55}$ Courts $^{56}$ have not held to be intrinsically unfair - ex art. 1469ter c.c. - those clauses which do not also cover the spouse, the children or any other relative living with the insured.

13. a) Are the parents under a duty to take out a liability insurance for their child?

34 No, under Italian law such a duty does not exist. ${ }^{57}$

b) Does the government do anything to encourage families to contract for insurance coverage, e.g. by requiring families in the course of admission of children to public schools to establish that they are covered?

35 There are no actual incentives to take out insurance for damage caused by minors. Such an insurance policy is not a prerequisite for admission to State schools. Unlike other areas - such as life assurance and professional indemnity insurance - where the insurance premium can be deducted from taxes due, there is no tax relief for the said insurance policy.

14. a) Do private insurance carriers enjoy rights of recourse as against the child in case they pay up a damage claim brought by the victim against the parents?

36 Art. 1916, sec. 2 c.c. provides that "except in the case of intent, there is no subrogation if damages are caused by children, adopted children (in Italian "figli affiliati", parents and grandparents, other relatives or related persons living together permanently with the insured or by servants". The Italian Constitutional court has added to this list the insured's spouse. ${ }^{58}$ Scholars explained the rule with two main policy arguments: 1) the insured person is already liable according to artt. 2048 or 2049 c.c. for the behaviour of the listed individuals $;{ }^{59}$ 2) the insured would not file an action against these tortfeasors anyway. ${ }^{60}$

${ }^{54}$ See Cass. 8 June 1988, no. 3890, [1988] Massimario della giustizia civile (Mass. Giust. Civ.), fasc. 6 .

${ }^{55}$ See Cass. 8 June 1988, no. 3890, [1988] Mass. Giust. civ., fasc. 6 and Cass. 18 October 1990, no. 10170, [1991] Giust. civ., 932 and [1991] GI, I, 1, 936.

${ }^{56}$ Trib. Roma 28 October 2000, [2001] Contratti, 441, with comment of A. Scarpello.

${ }^{57}$ On the ongoing debate for the introduction of a compulsory insurancee cover for parental liability see S. Patti (supra fn. 7), 33, V. Carbone (supra fn. 13), 504; L. Rossi Carleo, La responsabilità dei genitori ex art. 2048 c.c., [1979] Riv. dir. civ., II, 142.

${ }^{58}$ C. Cost. 21 May 1975, no. 117, [1975] Foro it., I, 1561.

${ }^{59}$ S. Toffoli, Commento sub art. 1916 in: A. La Torre (ed.) (supra fn. 52), 209.

${ }^{60}$ A. La Torre, Surroga assicuratoria: ancora sul concorso di colpa dell' assicurato danneggiato, [1978] Giust. civ., IV, 244 and L. Farenga (supra fn. 53), 141. 
b) Does the law of social security provide a limit on the right of recourse of the insurance carrier against the child or his parents or legal guardian?

No, there is no such a limit.

\section{E. Scope of Liability/Damages}

15. Is there a general limitation or reduction clause in cases of tort liabilities exceeding the financial means of the child or prospective adult?

The only limits are under (incapable) children liable in equity. Please refer to nos. 24-27.

16. If not, is there a discussion within domestic tort and/or constitutional law on the problem of excessive tort liability of minors?

No, although it has been shown that there is an increase in the number of trials in which the victim is a child. ${ }^{61}$ A large debate concerns litigation involving people with mental disorders, rather than children. There is an interesting proposal to introduce a "charter of minors' rights and duties". ${ }^{62}$

17. Does the domestic bankruptcy law or the law concerning the execution of money judgements allow individuals to obtain a discharge of debts which they are unable to pay off?

No, debtors must pay the entire amount owed. However, if debtors cannot pay their debts and have no assets of their own, it is obvious that creditors cannot recover their loss. Moreover, if the debtor is an entrepreneur, bankruptcy law intervenes. A minor 16 years old can be authorized to continue an entrepreneurial activity, in this case s/he is exposed to bankruptcy law as well.

18. If so, does discharge in bankruptcy also extinguish debts sounding in tort? If so, does it also apply to debts compensating the consequences of intentional acts?

No to both questions. Please refer to no. 41.

${ }^{61}$ See the statistics quoted in M. Rossetti, Il danno da lesione della salute (2001), 671 and F. Agnino, Il fatto repentino ed improvviso esclude la responsabilità dei precettori, [2002] DR, 285. Among criminal law experts see E. Calvanese/E. Mariani/V. Gazzaniga, Il minorenne omicida: dati di una ricerca svolta presso il Tribunale per i minorenni di Milano, [2002] Rassegna italiana di criminologia (Rass. it. criminol.), 437 et seq.

62 See M.T. Canzi Poggiato, Uno statuto per i minori?, [1994] Dir. fam. pers., 802 et seq. For a critical approach see P. Stanzione, Personalità, capacità e situazioni giuridiche del minore, [1999] Dir. fam. pers., 260 et seq. 


\section{Liability of Parents}

1. Are parents strictly liable for the tort of the child or does the parental liability depend on a breach of duty to supervise the child and thus on the fault of the parents?

42 One must bear in mind again the distinction between the respective applications of art. 2047 and art. 2048 c.c. Under the scope of the former, parents are liable as "supervisors" of a minor not capable of understanding or intending at the time s/he committed the act causing the injury. Under art. 2048 c.c., parents are liable as such when their child is liable in tort (please refer to nos. 3-6). ${ }^{63}$

43 In practice, case law has distinguished these two rules in the light of the burden of proof to be discharged in relation to parents, guardians etc. Under art. 2047 c.c., the person who has custody of the child must prove that s/he took all steps to keep the person incapable within the meaning of art. 2046 c.c. under control. On the contrary, under art. 2048 c.c., in order to escape liability parents must demonstrate they have provided suitable education for the child, so as to discourage him/her from behaving negligently.

44 Following the traditional interpretation of this provision by scholars, it actually reverses the burden of proof in favour of the victim ("relevatio ab onere probandi"). ${ }^{64}$ It can therefore be defined as fault-based liability. By contrast, another opinion stresses that fault is irrelevant in this case. ${ }^{65}$ This means that parents or other custodians are in theory always liable, unless they can prove that they were unable to avoid the act or omission and, consequently, the damage. Since the reversal of the burden involves the parents, etc. proving the absence of fault, the rule then fits into the category of semi-strict liability rules ("responsabilità semi-oggettiva"). ${ }^{66}$

${ }^{63}$ F. Giardina, voce Minore (supra fn. 1), 3.

${ }^{64}$ See R. Scognamiglio, Responsabilità per colpa e responsabilità oggettiva in: Studi in memoria di Andrea Torrente (1968), 1111; M. Comporti, Nuovi orientamenti giurisprudenziali sulla responsabilità dei genitori ex art. 2048 c.c., [2002] DR, 353 and F. Galgano, La commedia della responsabilità civile, [1987] Rivista critica diritto privato (Riv. crit. dir. priv.), 197. More recently, P. Morozzo della Rocca (supra fn. 11), 6 et seq. For the opinion of the courts, see Cass. 14 June 1952, no. 1701, [1953] GI, I, 1, c. 284 with comment of A. Trabucchi, Sulla prova liberatoria della presunzione di colpa esimente dalla responsabilità indiretta del genitore; Cass. 29 May 1992, no. 6484, [1993] GI, I, 1, 588. More recently, Cass. 10 July 1998, no. 6741, [1999] Resp. civ. prev., 107, with comment of A. Sbrighi Scotto.

65 A. Venchiarutti, La protezione civilistica dell'incapace (1995), 555.

${ }^{66}$ M. Comporti (supra fn. 31), 155; L. Corsaro, [1988] GI, 226 s., after referring the prevailing opinion that bases the liability rule provided for by art. 2048 c.c. on fault, stresses the different result reached by the courts. See also E. Bonvicini, La responsabilità civile per fatto altrui (1976), 629 et seq. 
Another highly debated issue is whether parental liability is linked to parents' misconduct or to the child's behaviour. According to one scholar, ${ }^{67}$ the answer may be found in the possibility of action against the tortfeasor (recourse). If such action is possible, we have a case of liability for the deed of another person (vicarious liability). If such recourse is not possible, as in this case, the source of liability is the conduct of the person obliged to pay damages. Note, however, that according to case law, the admissibility of an action depends on whether the child is capable of understanding or intending (action is admissible because there is a tort) or not (action is not admissible).

\section{If the parental liability is based on their own fault: Is the burden of proof on the victim or is there a rebuttable presumption of fault?}

There is a rebuttable presumption. Please refer to nos. 3-6. As already indicated, there is much debate as to the actual meaning of the expression "unless they prove that the act could not have been prevented" in art. 2047 c.c. A similar debate involves the proposition "if they prove that they were unable to prevent the act" in art. 2048 c.c.

As stressed from the outset and in order to simplify the reconstruction of the Italian system, it is better to distinguish case law concerning the supervision of an incapable adult ("incapace") and the supervision of a child. In the former case, courts generally take the view that the guardian must take all necessary steps to avoid the damage, considering the kind of incapacity which the person has ${ }^{68}$ It is important to emphasise that all possible sources of damage or danger must be removed from the environment. ${ }^{69}$ In the latter case, numerous conflicting judgments exist. ${ }^{70}$

However, judges generally express themselves in terms of culpa in educando when applying art. 2048 c.c. and culpa in vigilando when applying art. 2047 c.c. The first formula has justified court decisions holding parents liable although a child has caused damage while at school. In addition, courts have gradually made the burden of proof more difficult for parents to reverse. Indeed, liability arises when it is shown that parents had tolerated or encouraged any imprudence or abnormality in the minor's behaviour. Although it is theoretically necessary to prove causation between parents' behaviour and the damage sustained, very often liability is determined in light of the factual cir-

${ }^{67}$ M. Comporti (supra fn. 31), 169 et seq. See pages 165 et seq. for other scholars opinions. Courts state parents' liability for example in: Cass. 9 October 1997, no. 4945, [1998] DR, 254, with comment of F. Montaguti; Cass. 9 October 1997, no. 9815, [1998] DR, 254; Cass. 10 May 2000, no. 5957, [2000] Foro it., Rep., voce Responsabilità civile, no. 257.

68 See Cass. 28 June 1976, no. 2460, [1976] Mass. Giust. civ., 1065; Cass. 19 June 1997, no. 5485, [1997] Foro it., Rep., voce Responsabilità civile, no. 137. According to a decision (Cass. 10 March 1980, no. 1601, [1980] Foro it., I, 2526), it is necessary to prove that the lack of supervision is not attributable to the caretaker to avoid liability. Contra: M. Comporti (supra fn. 31), 195 et seq.

${ }^{69}$ Cass. 14 September 1967, no. 2157, [1968] Resp. civ. prev., 468.

${ }^{70}$ See, for instance, Cass. 5 April 1963, no. 880, [1963] Resp. civ. prev., 593. 
cumstances. ${ }^{71}$ This operates in a way similar to the presumption "res ipsa loquitur".

49 Prevailing case law stresses the need for the parents to actually show they have offered the minor an "education normally sufficient to provide a basis for correct social interrelation according to the surrounding environment, his or her habits and personality" "72. This interpretation leads, de facto, to the transformation of a theoretically negative burden of proof into a burden of proving positively the provision of education. ${ }^{73}$ Hence, judicial interpretation has changed the rule provided under art. 2048 c.c. ${ }^{74}$ Moreover, on some occasions, the facts of the tort committed have been held to be so serious as to preclude any possible evidence of proper education from the outset. ${ }^{75}$ In conclusion, one may observe that good education is relevant only when it leads to a concrete result: that is, that no damage has ever been caused. ${ }^{76}$

50 This judicial trend puts parental liability and masters' and employers' liability on the same footing, notwithstanding the fact that parents do not make a profit from their parental relationship. ${ }^{77}$ In the last analysis, parents can be considered as a sort of "insurance company" for third parties. ${ }^{78}$ A different reading, advanced by a minority of scholars, seems to reflect present-day family dynamics more accurately, by requiring parents to show only that they did not

71 See Cass. 16 May 1984, no. 2995, [1985] Dir. prat. ass., 311; Cass. 29 May 1992, no. 6484, [1993] GI, I, 1, 588; Cass. 4 June 1997, no. 4971, [1998] DR, 252, with comment of E. Montaguti; Cass. 26 November 1998, no. 11984, in DR, with comment of F. di Ciommo, Minore "maleducato" e responsabilità dei genitori; Cass. 9 October 1997, no. 4945 (supra fn. 67); Cass. 7 August 2000, no. 10357, [2001] Fam dir., 512, with comment of W. Finelli, Ancora sulla responsabilità del genitore per i danni causati dal figlio minore; Cass. 29 May 2001, no. 7270, [2001] DR, 1211 and [2002] NGCC, I, 326, with comment of A. Solinas, Responsabilità dei genitori per culpa in educando ed in vigilando. Criteri di determinazione.

72 Cass. 11 August 1997, no. 7459, [1997] Giust. civ., I, 2390; Cass. 24 October 1988, no. 5751, [1989] Arch. civ., 170; Cass. 26 June 1984, no. 3726, [1985] Arch. civ., 51; Trib. Verona 26 April 1979, [1981] GI, I, 1, 271; Cass. 25 May 1977, no. 2174, [1978] Resp. civ. prev., 422.

73 A. Pinori, [1995] GI, 556; M. Bessone, La responsabilità civile dei genitori tra presunzione di colpa e obbligo legale di garanzia, [1982] Giurisprudenza di merito (Giur. mer.), IV, 127.

${ }^{74}$ M. Bessone, Fatto illecito del minore e regime della responsabilità per mancata sorveglianza, [1982] Dir. fam. pers., 1012; U. Majello, Responsabilità dei genitori per il fatto illecito del figlio minore, [1960] Dir. giur., 44. See also M. Comporti, (supra fn. 64), 354 et seq., enumerating scholars' criticisms to the prevailing judicial trend.

75 Cass. 29 October 1965, no. 2302 (supra fn. 42); Cass. 16 May 1984, no. 2995, [1985] Dir. prat. ass., 311; Cass. 18 June 1986, no. 3664, [1986] GI, I, 1, 1525, with comment of A. Chianale, In tema di responsabilità dei genitori per i danni causati dai figli minori. Here also are useful comparative remarks. These hypotheses show a vicious circle: if parents show adequate surveillance or can justify their absence when the deed was committed it is usually required to show proper education to escape liability; but if proper education is shown, often courts argue that actually the deed reveals a peculiarly unrestrained attitude of the minor suggesting the necessity of a higher surveillance. Almost literally this way S. Patti, [1984] Riv. dir. comm., 31. See also E. Capaccioli, Responsabilità dei genitori per il fatto illecito del figlio minore, [1946] Riv. dir. comm., II, 259.

76 P. Morozzo della Rocca (supra fn. 11), 41; L. Rossi Carleo, [1979] Riv. dir. civ., 120.

77 See G. Alpa, Responsabilità civile e danno (1992), 304.

78 This way S. Patti (supra fn. 1), 269, and L. Corsaro, [1998] GI IV, 229. 
actually have any chance to prevent the child from doing the deed which caused the damage. ${ }^{79}$

With regard to "culpa in vigilando", the same trend we have highlighted previously can be identified. ${ }^{80}$ At present, case law evolution has established a stricter liability rule for parents, although it would be an overstatement to say they should control their children everywhere to avoid liability. ${ }^{81}$ It is obvious that the level of supervision decreases with the age of the minor. ${ }^{82}$

In order to reduce the extremely severe judicial reading of parental liability, some scholars have recently proposed ${ }^{83}$ keeping the "vicarious" nature of parental liability, but for it to be mitigated by the application of art. 2043 c.c. on all those occasions when damage has been caused "in the course of normal and free social, recreational and sporting activities". This reading would limit the scope of art. 2048 c.c. to "damage caused by the minor in intentional torts constituting a punishable crime or in the case of dangerous activities or abnormal and unusual conduct demonstrating reprehensible behaviour".

3. Who is subject to the parental duty to supervise: a) only the parents in a legal sense; $b)$ persons who have the right of custody; c) persons just living together with the child?

The duty to supervise a child is imposed, by law, primarily on parents and on the guardian chosen by the judge in the absence of the parents. The duty is exercised by each parent - as well as parental authority - and their liability is joint and several. ${ }^{84}$ In addition, the spouse of a parent is under a similar duty to

${ }^{79}$ Cass. 30 October 1984, no. 5564, [1985] Foro it., I, 145, with comment of M. Paganelli.

${ }^{80}$ Please refer to nos. 50 et seq.

81 See Cass. 15 October 1973, no. 2595, [1974] Resp. civ. prev., 432; Cass. 21 September 2000, no. 12501, [2001] Resp. civ. prev., 73, with comment of R. Settesoldi. Already A. Tabet, Questioni in tema di fatti illeciti dei minori, [1953] Foro it., I, c. 1432, more than half a century ago, wondered: "Devono i genitori impedire al figlio ventenne di uscire la sera?" (Must the parents forbid the 20year-old child from going out in the evening?). Note the possible side effects on education of such a prohibition. On these "side effects" see E. Maschio, Responsabilità ex art. 2048 c.c. e "grandi minori", [1988] Dir. fam. pers., 875 et seq.). Nevertheless, there are some recent decisions that can trigger a change in this judicial trend: Trib. Verona 18 February 2000, [2000] GI, I, 1409, with comment of F. Ferri, La responsabilità dei genitori ex art. 2048 c.c.; Cass. 28 March 2001, no. 4481, [2001] DR, 498, with comment of V. Carbone, Non rispondono i genitori per gli incidenti causati dal minore in motorino and in Familia, 2001, 1171, with comment of S. Patti.

82 See Cass. 30 October 1984, no. 5564, [1984] Resp. civ. prev., 385; Cass. 10 April 1988, no. 2738, [1989] Arch. civ., 46; Cass. 24 October 1988, no. 5751, [1989] Arch. civ., 170; Cass. 24 May 1994, no. 5063, [1995] Dir. fam. pers., 109. In a case involving the application of art. 2048 c.c. to tutors Cass. 20 August 2003, n. 12213, [2003] Guida al diritto-Il sole 24 ore, 40, 47 emphasized that culpa in vigilando must be evaluated "taking into account age and normal evaluation capacity of students case by case" ("in modo relativo, tenendo conto dell'età e del normale grado di valutazione degli alunni, in relazione al caso concreto").

${ }^{83}$ M. Comporti, [2002] DR, 360.

${ }^{84}$ See art. 316 para. 2 of the civil code: "La potestà è esercitata di comune accordo da entrambi $i$ genitori" ("The authority is exercised by both parents by mutual agreement"). Among different decisions see Trib. Palermo 4 January 1980, [1980] Rivista giuridica della circolazione e dei trasporti (Riv. giur. circol. trasp.), 771. Cass. 12 May 1981, no. 3142, [1981] GI, Rep., voce Responsabilità civile, no. 136 applies art. 2048 c.c. also to children born out of the wedlock. See S. Patti (supra fn. 1), 281. 
supervise the children of the other spouse, since there is a duty under art. 143 c.c. to provide moral and material help. ${ }^{85}$ Moreover, whoever in fact has custody of the child has a duty to supervise. Hence, all people who have custody of the child under a contract, or public assistance authorities, are under this duty. 86

4. If custody determines the duty to supervise: What are the rules for the allocation of custody in the following circumstances: a) children of unmarried parents; $b$ ) separation of married parents; c) divorce.

54 There is no difference between married and unmarried parents with reference to the duty to supervise a minor and further liability in case of tort. ${ }^{87}$ Whenever children live with both their parents (whether or not they are married), the parents have the same duty to supervise as long as they are living together. When parents do not cohabit, a judge decides which parent shall have custody. The same occurs in the case of separation or divorce, as provided by art. 155 c.c. ${ }^{88}$ Note that the judge may award joint custody, even though they are not living together.

5. Is the parent, who is not awarded the custody of the child and who does not live together with the child, subject to the duty to supervise?

55 In principle, the parent who is not awarded custody has no duty of supervision because the element of cohabitation is lacking. ${ }^{89}$ However, the parent who is not actually living with the child still has the authority and the duty to control the education and the living conditions of his/her child (art. 317bis c.c. and art. 155 para. 3 , c.c.). This may eventually trigger liability as well (please refer to nos. 46-52).

6. Which elements of a tort must the child have realized for the parents to be liable for it?

56 In order to trigger the application of art. 2047 c.c., children must have behaved in such a way that, but for their being incapable of understanding or intending, their action would have rendered them liable in tort. In order to trigger parental liability under art. 2048 c.c. the child must have committed a tort, i.e. all

85 A mutual obligation to loyalty, moral and material support, cooperation in the interest of the family and cohabitation derives from the marriage.

${ }^{86}$ M. Comporti (supra fn. 31), 222. Contra: C.M. Bianca (supra fn. 30), 699.

${ }^{87}$ See article 30, para. 3 of the Constitution: "La legge assicura ai figli nati fuori dal matrimonio ogni tutela giuridica e sociale, compatibile con i membri della famiglia legittima". Furthermore, see A. Chianale, Responsabilità dei genitori, [1988] Riv. dir. civ., 2, 278. Contra: M. Comporti (supra fn. 31), 221, who states the applicability of art. 2047 c.c. in such a case.

88 Art. 155 c.c.: "The court which decrees separation declares which of the spouses shall have custody of the children and makes all other provisions relating to the children, with exclusive reference to their moral and material interest." The text, with minor stylistic changes, is contained in art. 6, para. 2 of 1 L. 1 December 1970, no. 898 on divorce.

89 See Cass. 13 April 1979, no. 2195, [1979] Resp. civ. prev., 48. 
the elements of the tort committed by the child must be shown, including liability (delictual capacity). Please refer to no. 2.

7. What are the criteria for assessing the duty to supervise: a) factual situation (intensity of danger, etc.); b) circumstances in the person of the parent (disabilities, workload); c) circumstances in the person of the child (age, viciousness, accident-proneness, etc.)? In particular: Does the extent of the duty to supervise depend on whether (both of) the parents are working or not?

The most important requirement in applying art. 2048 c.c. is cohabitation, which courts interpret in a broad way. ${ }^{90}$ However, in the case of separation of married parents or of divorce, the courts' reading of cohabitation allows us to state that art. 2048 c.c. is not applicable to the parent who does not actually have custody of the child. However, in this case it is always possible to apply the general rule of tort liability (art. 2043 c.c.). ${ }^{91}$ When separation occurs " $d e$ facto", art. 2048 c.c. may be applied, owing to the temporary nature of the situation and the possibility of a new cohabitation.

The case in which a child has left home spontaneously is another controversial issue. This situation shows the likely cultural antiquity of the rule. The other criteria mentioned in the question are not applied for assessing the duty to supervise (factual situation, circumstances related to the parent or the child and the fact of whether the parents are working or not).

In cases of incapable persons, art. 2047, para. 1, c.c. uses the expression "charged with the custody" meaning that duties to supervise could arise from other sources than laws or contracts. The obligation to supervise may also arise from undertaking a particular role or task or responsibility freely accepted by the person undertaking it and acknowledged as such by others so as to acquire effect erga omnes. Such a case could be that of someone acting as host to a person incapable of understanding and intending at the time s/he committed the act. $^{92}$

8. To what extent are parents held to supervise their child during the time the child is attending school or at work?

Often, the meaning given by courts to the term "culpa in educando" is so broad that parents are held liable even when damage occurred while the child

90 See Cass. 20 April 1978, no. 1895, [1978] Archivio giuridico della circolazione e dei trasporti (Arch. giur. circ. trasp.), 510; Cass. 9 April 1976, no. 2115, [1976] Foro it., Mass., 459; Cass. 18 December 1992, no. 13424, [1992] Foro it., Rep., voce Responsabilità civile, no. 125. For an overview on several decisions: M. Comporti (supra fn. 31), 225 et seq. and A. Solinas (supra fn. 71$), 330$ et seq.

91 Art. 2043: "Any fraudulent, malicious, or negligent act that causes an unjustified injury to another obliges the person who has committed the act to pay damages."

${ }^{92}$ Cass. 1 June 1994, no. 5306, [1994] Fam. dir., 505, with comment of A. Figone. 
is at school, at work, or under the supervision of another adult such as the owners of a club. ${ }^{93}$

61 It is important to stress that courts have developed this argument only because the theory of "culpa in vigilando" was not applicable in those cases.

\section{Under which conditions may parents be held liable for acts of their children committed while they were living in boarding schools?}

62 Parents' liability is usually linked to art. 147 c.c., which obliges parents to maintain, educate and bring up their children, along with art. 30 of the Constitution. ${ }^{94}$ Criteria utilised by courts to assess the duty to supervise children imposed on their parents when the children live in a school are not different from those already discussed..$^{95}$ In other words, also in this case judges apply the argument of "culpa in educando". It is a truism to remark that the "culpa in vigilando" is not applied, because it requires physical proximity between parents and child.

10. What is the relation between the damage claim against the parents and the damage claim against the child?

63 Parents' liability may exist concurrently with that of the child, based on art. 2043 c.c., if the child has natural capacity ("capacità d'intendere o di volere"). ${ }^{96}$ However, they are independent from each other.

\section{Is there any possibility either for the child or the parents to have recourse against each other?}

64 When a minor with capacity caused damage and his/her parents have been held liable under art. 2048 c.c., the parents or guardians have a cause of action against him/her according to art. 2055 c.c. ${ }^{97}$ This is not possible, in the light of case law, against an incapable person (whether or not a minor).$^{98}$ In fact, there are no decisions reporting such an action against children or tortfeasors who are not capable. ${ }^{99}$

93 Cass. 10 February 1987, no. 1427, [1987] Resp. civ. prev., 828. For criticisms to the role of culpa in educando see A. Chianale (supra fn. 75), 1536.

94 " $\grave{E}$ dovere e diritto dei genitori mantenere, istruire ed educare $i$ figli, anche se nati fuori dal matrimonio" (omissis). (Translation of the author: "It is a duty of the parents to maintain, instruct and educate their children even if born outside of marriage.") We must take into account the differences between today's society and that of the 1940s, when the c.c. was enacted: M. Comporti (supra fn. 31), 246 et seq.

${ }^{95}$ Please refer to nos. 57 et seq.

96 See Cass. 13 September 1996, no. 8263, [1997] Studium Juris, 80; Cass. 3 March 1995, no. 2463, [1995] GC, I, 2093; Cass. 26 June 2001, no. 8740, [2001] Foro it., I, 3098.

97 Art. 2055 c.c.: "If the act causing damage can be attributed to more than one person, all are liable in solido (art. 1292 c.c.) for the damages."

98 See Tribunale Roma, 28 May 1987, [1988] Riv. giur. circol. trasp., 635.

${ }^{99}$ Furthermore, see nos. 42-45. 


\section{Liability of Other Guardians and of Institutions}

1. Who is subject to a duty to supervise those children who have no parents in the legal sense

The duty to supervise children who have no parents in the legal sense is imposed by law upon the people or the institutions chosen as guardians by the judge. ${ }^{100}$ However, an old decision which still seems relevant today found a married couple liable, who had been chosen to undertake temporary custody (which is called "affidamento preadottivo" under Italian law), rather than the institution which had official custody. ${ }^{101}$ The decision was based only on the spouses' actual authority to control the child. We can infer from this case that actual authority to control triggers a duty, in the absence of formal delegation of a duty to supervise. Please refer also above under nos. 57 to 60 .

2. Who is subject to a duty to supervise while the child is trained in a private business enterprise or simply working there?

First of all, we must remember that minors are not allowed to work until they are at least 15 years old (law no. 345/1999). However, art. 2048, para. 2, c.c. provides for a duty of the employer to supervise the child. ${ }^{102}$ It is a debated issue whether or not the list set out in art. 2048 c.c. can be interpreted extensively by analogy. ${ }^{103}$ Moreover, art. 2047 c.c. establishes a general duty to supervise the incapable person ("incapace") and this rule is applicable to the case in which an incapable child or a mentally ill person works, which is allowed in some circumstances by law, or when the person is temporarily unconscious. We should remember also that art. 2049 c.c. provides for employers' liability for damage caused by their employees. ${ }^{104}$

3. Who is subject to a duty to supervise when the child is living in a children's home, a boarding school or other institution?

The duty to supervise is assessed by law to the person who exercises actual control and authority over the child. ${ }^{105}$

100 See art. 2047 and 2048 c.c. and no. 54

101 App. Napoli, 7 November 1966, [1967] Rivista di diritto minerario, 312. See also A. Chianale, [1967] Riv. dir. civ., 278.

102 "Teachers and others who teach an art, trade, or profession are liable for the damage occasioned by the unlawful act of their pupils or apprentices while they are under their supervision. The persons mentioned in the preceding paragraphs are only relieved of liability if they prove that they were unable to prevent the act."

103 In the positive sense, P. Morozzo della Rocca (supra fn. 11), 48; in the second and negative sense, A. De Cupis, Dei fatti illeciti in: Commentario al codice civile Scialoja-Branca (2nd edn. 1971), 58.

104 Art. 2049: "Masters and employers are liable for the damage caused by an unlawful act of their servants and employees in the exercise of the functions to which they are assigned." See also Cass. 12 November 1979, no. 5851, [1979] Foro it., Rep., voce Responsabilità civile, no. 1368; Trib. Roma 28 May 1987, [1988] Riv. giur. circol. trasp., 635.

105 Furthermore, see nos. 42-45. 
4. May a duty to supervise be established by means of private contract? If so, does such contract reduce in any way the duty of the person originally charged with the duty to supervise?

68 Courts apply art. 2047 c.c. to whoever agrees to supervise a child, even " $d e$ facto" or just for a limited period. ${ }^{106}$ If the persons originally charged with the duty to supervise are the parents, their liability may not be reduced by the mere fact that a duty to supervise has been imposed on others, if they are sued under art. 2048 c.c.

5. What are the legal principles concerning schools for the duty to supervise pupils? Is it a matter of public administrative law or of (private) tort law?

69 Art. 350 of the Regio Decreto 26 April 1928, no. 1297 provides for the regulatory regime for teachers' duties of supervision in primary school ("scuola elementare"). The duty to supervise of secondary school teachers ("scuola media") is provided for by the Regio Decreto 30 April 1924, no. 965.

70 Briefly, teachers must be present when pupils come into the school and when they exit; they must supervise the children during both classes and breaks; they must guarantee hygiene and they must give first aid in cases of emergency.

71 The Decreto del Presidente della Repubblica 10 January 1957, no. 3 (the socalled "Testo unico degli impiegati civili dello Stato" setting out duties and rights for civil servants), introduced a specific liability regime for civil servants. It limits their liability to intentional torts and torts caused by gross negligence (artt. 22 and 23). Nevertheless, the main judicial trend is to apply the same liability regime provided for other fields. ${ }^{107}$ Art. 61 of law 11 July 1980, no. $312^{108}$ confirmed the specific regime for civil servants, establishing its ap-

106 See Cass. 12 May 1981, no. 3142 (supra fn. 84); Cass. 10 April 1988, no. 2738, [1989] Arch. civ., 46; Cass. 1 June 1994, no. 5306, [1994] Fam. dir., 505. See G. Vidiri, Danno al "lupetto" e responsabilità dell'associazione scout, [1998] DR, 182.

107 See Cass., sez. un., 9 April 1973, no. 997, [1973] Foro it., I, 3091, with comment of M. Grossi. See also E. Casetta, L'illecito degli impiegati civili dello Stato, [1956] Rivista trimestrale di diritto pubblico (Riv. trim. dir. pubbl.), 436; G. Landi/G. Potenza, Manuale di diritto amministrativo (1971), 308; D. de Strobel, Culpa in vigilando di genitori, tutori, precettori e maestri d'arte, [1969] Dir. prat. ass., 16; F. Ferrero, La responsabilità civile degli insegnanti statali per gli atti illeciti degli alunni. Deroga alla presunzione ex art. 2048 c.c. per effetto degli artt. 22 e 23 del T.U. n. 3 del 1957, [1974] Arch. resp. civ., 15 and L. Corsaro, Sulla natura giuridica della responsabilità del precettore, [1967] Riv. dir. comm., I, 38. More recently: S. Baccarini, La responsabilità penale, civile ed amministrativa degli insegnanti nell'esercizio della funzione docente, [1980] Resp. civ. prev., 454; S. Baccarini, La responsabilità civile degli insegnanti e dei dirigenti scolastici (1981); M. Bessone, La ratio legis dell'art. 2048 c.c. e la responsabilità civile degli insegnanti per il fatto illecito dei minori, [1982] Foro pad., I, 304; G. Moneta, Note in tema di responsabilità civile del personale scolastico statale dopo la legge n. 312 del 1980, [1988] GI, IV, 49 and G. Scalfi, La responsabilità civile dell'insegnante statale dopo le innovazioni del 1980, [1989] Resp. civ. prev., 987.

108 Nowadays, the provision is included in art. 574 d. lgs. 297/1994, the so-called "Testo unico delle disposizioni legislative vigenti in materia di istruzione, relative alle scuole di ogni ordine e grado." 
plicability to State school teachers and providing that the plaintiff's claim can be made only against the public administration. The Italian Constitutional Court endorsed the constitutional legality of these rules. ${ }^{109}$ Thus, in general terms, we can say this is more a matter of administrative law rather than private law.

Schools are usually insured against accidents happening to their students and they are obliged to pay the agreed premium to the insurer (art. 1882 c.c.) and must report the accident (art. 1913 c.c.). The right to indemnity arising from the contract has a limitation period of one year from the accident (art. 2952 c.c.). Although the contract is valid, in the case of late payment or failure to pay the first instalment of the premium, the insurer can refuse to pay the claim because the insurance cover was not operating at the time the accident happened. In fact cover operates from 12 p.m. of the day following the payment. However, in the case of late payment of an instalment subsequent to the first, the cover is suspended only after the fifteenth day after the date payment was due. The coverage resumes at 12 p.m. of the day after the payment has been made (art. 1901 c.c.).

6. Who is liable for accidents caused by pupils in public and private schools: The teacher, the school, the education authority or the state?

First of all, it is necessary to take into account the principles illustrated before (nos. 69-72 especially no. 71). While it is clear that art. 2048 c.c. is applicable to teachers in primary and secondary schools, its applicability to professors is rather controversial, since liability does not only imply teaching, but also supervising. ${ }^{110}$ For example, it was held that liability under art. 2048 c.c. arises when a teacher carries out a specific activity, although s/he acted as a substitute for another teacher. ${ }^{111}$ Therefore, prima facie, the teacher is liable; however, both State schools and private schools may be liable as well (see art. 2049 c.c. and please refer to supra no. 67).

Art. 2, sec. 1, Lit. b of D. lgs 19 September 1994, no. 626 declares the employer responsible for the application of accident prevention rules and regulations, the protection of employees and workplace safety. The D. lgs 19 March 1996, no. 242 modified the d.lgs 626\1994 with reference to accident prevention in the civil service. The new statute emphasises that the manager or the civil servant, even if they do not have the position of director, can be equated with the employer if they have been expressly put in charge of an independent unit and this has been confirmed in writing. These directors must ensure the safety rules are observed: to appoint the person in charge of the safety system;

109 See C. Cost. 24 February 1992, no. 64, [1992] GI, I, 1, 1618, with comment of M. Comba, Ulteriore estensione della responsabilità dell' Amministrazione ex art 28 Cost.

110 M. Comporti (supra fn. 31), 278 and A. Lanotte, Condotta autolesiva dell'allievo: non risponde l'insegnante, [2003] DR, 51, note 1.

111 See Cass. 26 April 1996, no. 3888, [1996] Foro it., Rep., voce Responsabilità civile, no. 138; Cass. 10 June 1994, no. 5663, [1994] Giust. civ., Mass., fasc. 6. 
prepare a risk prevention plan; to monitor procedures which have been identified as risky; to monitor the safety equipment and action taken.

75 In State schools it is the "head teacher" who is treated as the employer with regard to health and safety at work. In this capacity s/he must fulfil the above mentioned duties. In private schools, the 'employer' is the "headmaster/headmistress", who has the same duties and liability as the head teacher in State schools with regard to accident prevention for protecting both employees and students.

76 The "head teacher" (called "preside" in secondary and high schools) who organises and supervises the teaching activities must co-operate with the "head administrator" in the correct application of the statutory rules and in identifying specific risks. However the "preside" is not directly responsible for the fulfilment of safety duties towards the employees (teachers or not) and the students. The "head", as employer, is liable for the failure to apply the safety rules and regulations and possibly for the violation of rules for the prevention of industrial accidents.

7. In public schools: Given that the state is liable for the failure to supervise, may the state entertain a right of recourse against the teacher or the school?

77 In State schools, the right of action in favour of the administration against civil servants is restricted to intentional torts and torts caused by gross negligence (art. 61 of law 312/1980). We must stress that only the State may be sued. ${ }^{112}$

\section{Same question with respect to private schools: May the school entertain a recourse action the teacher who has failed to supervise?}

78 Although there are no existing decisions on this point, according to general rules of liability it is clear that private schools can sue their teachers and employees. This right can be limited or removed by a collective labour agreement. We should remember also that strict liability of schools exists concurrently with the teacher's liability. However, schools do not need to prove the gross negligence of the teacher in order to have a cause of action, as, conversely, happens in State schools.

112 Ex plurimis, see Cass., sez. un., 11 August 1997, no. 7454, [1998] Resp. civ. prev., 1071, with comment of R. Settesoldi, La responsabilità civile degli insegnanti statali: l'obiter dictum delle Sezioni unite segna definitivamente il tramonto della presunzione di culpa prevista dall'art. 2048, comma 2 c.c.?, [1998] DR, 260, with comment of M. Rossetti; Cass. 3 March 1995, no. 2463, [1995] GC, I, 2093; Cass. 10 February 1999, no. 1135, [2000] GI, 507, with comment of V. Pandolfini, Sulla responsabilità dei precettori e dell'ente scolastico per il danno cagionato dall'allievo a sé medesimo; Cass. 4December 2002, no. 17195, [2003] Giust. civ., I, 1826. Sometimes courts do not even require to ascertain which teacher did not comply with his/her duty of surveillance since the action can be exercised only against the State. See for example Trib. Milano 3 June 1985, [1985] Foro pad., 376, with comment of V. Frattarolo. See on State liability for torts committed by civil servants M. Giracca, Responsabilità civile e pubblica amministrazione: quale spazio per l'art. 2049 c.c.?, [2001] Foro it., I, 3293. 
9. What are the criteria for assessing the extent of the teacher's duty to supervise?

It is not clear whether or not art. 2048 c.c. is applicable to State school teachers. ${ }^{113}$ Usually, courts state that the scheme of exceptions provided for civil servants is consistent with the liability provided for in the civil code. In any event, the level of supervision must be assessed according to the age of pupils. ${ }^{114}$ To rebut the presumption of liability, it must be shown that the child's misbehaviour was so unforeseeable that it could not have been prevented. ${ }^{115}$

In general terms, all school employees have a duty to prevent damage to students in the course of school life. Their liability varies according both to diversity of situations (e.g. students' age, or their peculiar personal conditions) and role. However, this duty is limited to actual working hours. Therefore, for example, the teacher has a duty to be in class during the teaching time and is liable only for damage occurring within this time frame. ${ }^{116}$

A specific regulation deals with the case of students arriving at school earlier than expected or whose parents pick them up later (so called "pre-school activities"). An agreement signed on 12 September 2000 leaves the organisation of "pre-school activities" and the appointment of responsible individuals in the event of damage arising, to specific agreements between the local authority and the school. Table A of national agreement for schools (C.C.N.L. 16 May 2003 for "comparto Scuola") attributes the duty of surveillance to the administrative employees (so called "personale A.T.A.") both before lessons start and during recreation time. ${ }^{117}$

In high school, students have their assemblies, during which a different set of rules applies. ${ }^{118}$ Schools' employees still have a duty to guarantee students' safety through "external vigilance" and the power to intervene in the case of danger or disorder. According to art. 14 "the preside has the power to intervene in case of violation of the assembly rules or when it is impossible to continue the assembly in an orderly way". To this end, the preside or a repre-

113 M. Comporti (supra fn. 31), 286 et seq. Cass. 18 April 2001, no. 5668, [2001] Foro it., I, 3098, with comment of F. di Ciommo; Cass., sez. un., 21 December 1999, no. 916, [2000] GI, 1043; Cass. 26 June 1998, no. 6331, [1999] Foro it., I, 1574, with comment of F. di Ciommo, Danno "allo" scolaro e responsabilità "quasi oggettiva" della scuola, seem to apply it. Cass., sez. un., 11 August 1997, no. 7454, [1998] Resp. civ. prev., 2390; does not apply.

114 Trib. Reggio Emilia 18 March 1992, [1983] Riv. giur. scuola, 511, with comment of G. Bondoni; Cass. 10 December 1998, no. 12424, [1997] Giust. civ., Mass., 2560.

115 Cass. 21 August 1997, no. 7821, [1997] Giust. civ., Mass., 1871.

116 According to a decision, the fact that the teacher is on another duty (namely a committee meeting) during class hours, leaving the students in custody of an assistant, does not exclude his/her liability. See for example Corte dei Conti 1 June 1987, no. 542, [1987] Riv. Corte Conti, I, 1090.

117 However, the duty of surveillance remains also during recreational time: see Cass. 6 February 1970, no. 263, [1970] GI, I, 1, 852 and the more recent decision rendered by Trib. Firenze 19 March 1993, [1993] Arch. civ., 561.

118 See art. 12 ss. D.lgs. 16 April 1994, no. 297. 
sentative may remain in the assembly room (art. 13, sec. 8) or close to it. No teacher, except the preside, can exercise this power with the corresponding duties and liability. The above described rules are the normative parameter for assessing liability in cases requiring intervention, which in fact was not carried out.

83 The same surveillance regime applies in the case of other activities - such as recreational ones, sight seeing, etc. - outside the school and possibly outside the regular school hours. ${ }^{119}$ School employees are liable for damage to the students, even if caused by other students, only when there is an intentional omission or gross negligence in surveillance. However, before engaging in any extracurricular activity, it is usual to inform the family of the whole programme and to ask them to put the students directly under the responsibility of the accompanying teachers, not the school. Such consent to the extracurricular activity is decisive in attributing liability. Moreover, when the student is entrusted to a teacher not belonging to the school, the teacher assumes professional liability for the organisation and management of the recreational, educational or sporting activity.

84 In the case of an accident occurring during these activities, damage can not be imputed to the accompanying teacher if s/he could have not prevented the event or could not have taken any further steps to avoid the accident. For example, the accompanying teachers are not liable for damage sustained while skiing, since entrusting the students to ski instructors does not constitute a negligent lack of surveillance. ${ }^{120}$

85 If teachers are on strike, the surveillance of students can be entrusted to nonteaching employees or other teachers not on strike. Alternatively, by notifying the families, it is possible to let the students leave the school earlier than scheduled. Note that the rule also applies to students who are over 18 years of age. $^{121}$

10. What is the relationship between damages claims against teachers, schools, school-boards, public authorities sounding in tort on the one hand and social security benefits on the other? May damages be recovered from the teacher or school authority for those heads of damages which are covered by social security benefits? Do social insurance carriers enjoy rights of recourse against teachers, schools, school-boards and the state?

86 Under Italian law, there are no specific rules about collateral sources. The general compensation rule is that all damages (but only those incurred) should be compensated. Therefore, we can say that the social security benefits are con-

119 Ex plurimis, Trib. Reggio Emilia 18 March 1982, [1983] Riv. giur. scuola, 511.

${ }^{120}$ Corte dei conti, 27 April 1993, no. 104, [1993] Riv. corte conti, 95.

${ }^{121}$ See circ. Ministero Pubblica Istruzione no. 38923 November 1982 and art. 7 Decreto del Presidente della Repubblica (D.P.R.) 31 May 1974, no. 420. 
sidered in determining the amount of damages. Expenses incurred by the national health system ("servizio sanitario nazionale") are not recoverable. The system is based upon contribution from all citizens and the users, sometimes, are obliged only to pay a small fee to share the expenses incurred by the system. ${ }^{122}$

11. What is the relation between the damages claim of the victim against the child and his damages claim against the teacher or other institution liable for the tort of the child?

The claims against the child and/or the parents can be joined simultaneously with the claim against the teacher (rectius: the State, for State school teachers). For example, parents can be negligent in educating ("culpa in educan$d o ")$ and the teacher can be negligent in supervising ("culpa in vigilando"). Furthermore, the child may also be liable according to art. 2043 c.c., ${ }^{123}$ if capable of understanding and intending when the act or omission was committed.

\section{Is there any possibility either for the child or the teacher to have recourse against each other?}

There are no existing decisions on this point. However, according to general rules, teachers can take action against a pupil-tortfeasor who is liable in tort as well. Yet, we must recall that an injured party cannot directly sue a State school teacher, ${ }^{124}$ and that a teacher can be ordered to refund the State only in the case of gross negligence or intent, ${ }^{125}$ These requirements severely limit the actual possibility to take such actions. With reference to child's action against the teacher, it is obvious that the teacher can defend him/herself by proving the contributory negligence of the child. Moreover, art. 2048 c.c. does not apply if damage to a pupil is due to his/her own negligence. ${ }^{126}$ Indeed the policy reason

122 See Law 23 December 1978, no. 833.

123 Cass. 21 September 2000, no. 12501, [2001] Resp. civ. prev., 73; Cass. 10 May 2000, no. 5957, [2000] Foro it., Rep., voce Responsabilità civile, no. 257.

124 See Cass. 21 September 2000, no. 12501, [2001] Resp. civ. prev., 73.

125 See A. Ferrari/E. Folgheraiter/G. Furlani, La gestione contabile della scuola. Funzioni, compiti e responsabilità del direttore didattico o preside, del segretario e degli organi collegiali (1982).

126 Cass. 10 February 1999, no. 1135, [2000] GI, 507; Cass 28 July 1967, no. 2012, [1968] Riv. circol. trasp., 390; Cass. 12 July 1974, no. 2110, [1975] GI, I, 1, 70; Cass. 13 May 1995, no. 5268, [1996] NGCC, 1, I, 239, with comment of A. Zaccaria, Sulla responsabilità civile del personale scolastico per i danni sofferti dal minore; App. Firenze 17 April 1964, [1964] Giur. tosc., 748; App. Milano, 22 March 1974, [1974] Arch. civ., 258; Trib. Roma 2 October 1997, [1998] Giur. romana, 1, 27. Among scholars see M. Franzoni (supra fn. 38), 351; M. Franzoni, Illecito dello scolaro e responsabilità del maestro elementare, [1997] DR, 454; L. Corsaro, [1967] Riv. dir. comm., I, 38; S. Patti (supra fn. 1), 258; F. di Ciommo, L'illiceità (o antigiuridicità) del fatto del minore (o dell'incapace) come presupposto per l'applicazione dell'art. 2048 (o 2047) c.c., [2001] Foro it., I, 3100. Contra: C.M. Bianca (supra fn. 30), 701; Cass. 3 February 1972, no. 260, [1972] Foro it., I, 3522, with comment of M. Grossi; Cass., sez. un., 11 August 1997, no. 7454, [1998] Resp. civ. prev., 2390; Cass. 26 June 1998, no. 6331, [1999] 
behind the rule is the protection of third parties damaged by a minor's tort. In case of damages to a pupil caused by his/her own negligence the general rule of liability for fault applies (art. 2043 c.c.). ${ }^{127}$ More recently, courts have also applied the contractual liability rule (art. 1218 c.c.) because the burden of proof for the victim is lighter. ${ }^{128}$

13. What is the relation between the teacher's duty to supervise and the parental duty to supervise? Is there any possibility either for the teacher or the parents to have recourse against each other?

89 Please refer to nos. 65-72 and 87 , for the general framework.

90 In principle they might have causes of action if they are all liable. For example, parents may have violated their duty to educate and teachers their duty to supervise. Whoever is held liable for the whole damage can have a claim pro quota against the other(s).

Foro it., I, 1574; Trib. Messina 28 November 2001, [2002] Foro it., I, 602. See also N. Daniele, La responsabilità dell'amministrazione scolastica per i danni recati dall'alunno a sé stesso, [2000] Riv. giur. scuola, 157; V. di Spirito, La responsabilità del personale della scuola per gli infortuni degli alunni, [1998] Lavoro e previdenza oggi, 1934; S. Masala, Sulla applicabilità della disciplina dell'art. 2048 c.c. (relativa alla responsabilità degli insegnanti per il fatto illecito degli allievi) nel caso in cui l'allievo procuri un danno a sé stesso, [2000] Rivista giuridica sarda, 59.

127 Cass. 10 February 1999, no. 1135, [2000] GI, 507.

128 This conclusion seems to provide for liability for mere "social contact". See Cass., sez. un., 27 June 2002, no. 9346, [2002] Foro it., I, 2635, with comment of F. di Ciommo, La responsabilità contrattuale della scuola (pubblica) per il danno che il minore si procura da sé: verso il ridimensionamento dell'art. 2048 c.c., [2003] DR, 46, with comment of A. Lanotte, Condotta autolesiva dell'allievo: non risponde l'insegnante. In dottrina, in tal senso, F. di Ciommo, Danno "allo" scolaro e responsabilità "quasi oggettiva" della scuola (supra fn. 113), 1575; F. di Ciommo, Figli, discepoli e discoli in una giurisprudenza "bacchettona"?, [2001] DR, 266. On these issues see also M. Rossetti, Responsabilità civile, le grandi decisioni della Corte nell'anno 2002, [2003] Diritto \& Giustizia, 57. 